\title{
Cooperative Collection Development for Rare Books Among Neighboring Academic Libraries
}

\section{Martha M. Smith}

Coordination in rare book acquisitions occurs on a unilateral basis when one librarian does not select certain books because a neighboring collection has extensive holdings in the same area. Few attempts, however, have been made to cooperate in rare book collection development on a multilateral basis whereby librarians jointly agree to select books in assigned subject areas. This article studies the characteristics of a multilateral cooperative selection program for small rare book collections and describes the success of such a program at the University of North Carolina-Chapel Hill and the University of North Carolina-Greensboro.

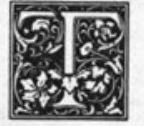

he phenomenal technological innovations developed in recent years have enabled people to access a vast quantity of information more quickly than ever before. Microforms enable a research library to house more books and journals; computers instantaneously compile and print a subject bibliography or display selected abstracts of articles. Thus, in an age when high priority is given to convenient spaceand time-saving devices, one might think that microforms and computers would have superseded in popularity the traditional form of recording facts and ideasbooks. But despite the efficient control and dissemination of information by these modern tools, they can be only "used," that is, skimmed or consulted partially. Books, however, can be "read," that is, studied and reflected upon, underlined and annotated. The book, therefore, will remain instrumental to scholarship. ${ }^{1}$

Especially worth reading are the books that record man's most significant ideas and actions. Rare book collections pre- serve these titles and others that, for varying reasons, are considered special. One may find a title's several issues or editions, perhaps the author's annotated copies, that reveal steps in the development of a philosophical idea, a poem, or a literary character. Here also are original accounts of events, now a part of history, and contemporary analyses of them. Such books are influential because they spark in us an awareness of our predecessors. It is "the historical sense," wrote T. S. Eliot, that "involves a perception, not only of the pastness of the past, but of its presence. ${ }^{\prime 2}$ Intellectual sensitivity is a characteristic of the mature scholar, who, through the study of books, produces new ideas or integrates old ones into fresh interpretations for the benefit of present and future generations. Rare book collections play an important role in research because they preserve these books for study.

Conditions during the 1980 s have presented rare book librarians with formidable obstacles to surmount in order to ensure the growth and sometimes the very

Martha M. Smith is assistant librarian for the Eighteenth-Century Short-Title Catalogue/North American Project, College of Arts and Sciences, Louisiana State University, Baton Rouge 70803-5111. 
existence of their collections. Static or declining budgets and increased competition for books, due to the limited availability of established rarities, pose major problems for librarians with collections of under 100,000 titles. Librarians may solve some of these problems by the same methods used in building general collectionscooperative collection development and resource sharing. Indeed, little-used library materials, those "resources held in reserve," present themselves most readily for sharing, and cooperation among special subject repositories and archives has been endorsed already. ${ }^{3}$ Some rare book curators, content with independence in building their collections, may reject the idea. Yet modification of selfsufficiency into cooperation is essential if research libraries are to meet their responsibilities to higher education. ${ }^{4}$ Interdependence seems to be inescapable. Moreover, "functional independence . . . is really inconsistent with the character of knowledge itself. ${ }^{\prime 5}$ The more important goal is not the acquisition of a greater number of books, but rather improvement in the availability of a greater number of books. ${ }^{6}$ One can then operate more effectively with available monies or while coping with a stationary or decreasing acquisitions budget.?

A cooperative collection development program divides acquisition responsibilities among libraries. Out of this grows resource sharing or use of materials at one library by the patrons of other participating libraries when such materials are not available at their own institution. For most libraries, resource sharing is accomplished by interlibrary loan; books move from library to library as they are needed by readers. Special collections materials, however, cannot be sent by interlibrary loan. Because of their value or fragility, rare books are kept in one location, eliminating the risk of loss or damage that might occur in sending them between libraries. It is the researcher who moves from library to library to study them. In view of this situation, resource sharing to meet scholars' needs in rare book collections may be best achieved through cooperation among neighboring libraries; proximity of materials greatly reduces the cost and inconvenience of travel for the researcher.

The ACRL Rare Books and Manuscripts preconference (Philadelphia, July 1982) was entitled "Growth in the Face of Adversity: The Business of Special Collections in the 1980s." Attendees heard David Stam address this theme in the keynote address, urging collaboration rather than isolation among special collections in order to preserve their usefulness and value. In this article, guidelines for cooperation in acquisitions for small rare book collections are offered. These guidelines and the success of the cooperative program at the University of North Carolina can serve as an example from which others may profit.

\section{A BRIEF HISTORY}

One means of coordinating selection in library collections is on a unilateral basis. This occurs when Librarian A does not acquire a certain book because Librarian B at a neighboring collection has already developed extensive and more complete holdings, which it would complement better. No discussions or written policies are shared by the two curators. Librarian $\mathrm{A}$ is coordinating acquisitions by default with those of Librarian B. ${ }^{8}$ This practice has existed in the past among regional special collections. In 1948 Lawrence Powell stated that the Clark Library at UCLA seldom purchased a book published before 1640 because of the strong collection of these imprints held by the nearby Huntington Library. ${ }^{9}$ In recent years, the University of North Carolina at Chapel Hill (UNC-CH) has deferred to Duke University in the purchase of Aldines, books published by Aldus Manutius and his family in Venice, 1490-1590. While UNC$\mathrm{CH}^{\prime}$ s Rare Book Collection would like to build up its sixteenth-century holdings, such a title might be more valuable if added to Duke's handsome Aldine collection. UNC-CH can then acquire another sixteenth-century rarity and possibly also have the Aldine available six miles away for its researchers. ${ }^{10}$ Numerous other rare book librarians today will admit to selecting while being mindful of a neighboring 
institution's collections.

A second means of coordinating book selection is multilateral cooperation in which librarians at separate institutions actively coordinate their acquisitions and mutually benefit from their efforts. ${ }^{11}$ In the words of one librarian, it "requires more energy, communication and commitment." ${ }^{\prime 2}$ Under multilateral cooperation, the librarians discuss and divide among themselves responsibilities for book selection in specific areas. The agreement is formalized in writing. Flexibility is built in by permitting necessary duplication and change of collecting fields. Neighboring rare book collections using the multilateral approach may benefit in several ways. Individually, each collection continues to grow in size while competition for titles on the market is reduced; jointly, rare book librarians are able to preserve research materials encompassing an improved breadth and depth in subject collection levels. Use of the collections may increase, and the libraries are able to affirm to their respective institutions their importance in maintaining research and teaching standards and to establish among outside researchers a reputation of being a locale where one may study a subject extensively.

Some suggestions for multilateral cooperation in rare book acquisitions were made during the 1960s and 1970s. In the introduction to his short-title catalog of books printed between 1641-1700 and held in Australian libraries, W. J. Cameron proposed a coordination of acquisitions among Australian libraries in seventeenth-century British literature. $\mathrm{He}$ suggested that participating libraries assign responsibilities for gathering the works of individual poets, dramatists, and essayists according to each institution's preexisting strengths. The library with the largest holdings on a famous writer like Milton would be given the sole responsibility for collecting his works. Writers who collaborated might be collected by only one library; for example, Nathaniel Lee's plays would enhance a group of John Dryden's writings because the two worked together. If more than one library had developed collections of a specific author or genre, responsibility would be assigned to the library that could assemble the best collection of supportive materials. ${ }^{13}$

Another suggestion for multilateral cooperation was made in 1970 for the special collections of seven New England institutions comprising the Connecticut Valley Libraries (CONVAL). Investigation revealed that the libraries at Amherst, Bowdoin, Dartmouth, Smith, Trinity, Williams, and Wesleyan had collected incunabula and/or private press books on the history of the printed book and book arts. Consequently, it was suggested that the special collections librarians might meet and exchange information on private presses holdings. Libraries could be selected to obtain complete runs of certain presses' work. $^{14}$ The idea, however, was not implemented, and nine years later, the librarians at the institutions explained its failure in several ways. The tradition of independence and competition among the colleges, the long distances between the libraries, and a keen desire to have books immediately available for teaching undergraduates were barriers to a division of collecting fields. Furthermore, certain books most appropriately housed at one collection were considered useful at all the libraries, and librarians were reluctant to refuse gifts solely because they might duplicate private press books held elsewhere. Finally, the librarians relied heavily on gifts and financial contributions designated for certain kinds of purchases, thereby allowing a collection's scope, to a certain extent, to be defined by the interests of the donors. ${ }^{15}$

\section{GUIDELINES}

In 1979 a cooperative collection development policy was drawn up for the Rare Book Collection at the University of North Carolina at Chapel Hill and the Department of Special Collections at the University of North Carolina at Greensboro (UNC-G). It will be discussed later in detail, but experience shows that a program may be implemented successfully following the guidelines listed below. Further suggestions may be found in the draft of a guide for coordinated collection development approved by the Resources Section 
of ALA's Resources and Technical Services Division. ${ }^{16}$

There are five guidelines that should be treated as prerequisites to the formal agreement. First, proximity of the cooperating institutions is essential. ${ }^{17}$ As mentioned above, distance was an obstacle for the CONVAL libraries. Closeness facilitates personal meetings of the librarians negotiating the policy. More important, it fosters concurrent use of the collections by researchers in the area. On coordinated visits, patrons have a greater number of books at their fingertips while keeping at a minimum the high travel costs, both in time and money, of research.

A positive attitude on the part of the librarians is the second prerequisite to an agreement. Especially important are a willingness to cooperate and to contribute and a mutual respect among the participants for each other. ${ }^{18}$ Enthusiasm to experiment and to try new approaches should be demonstrated. ${ }^{19}$ Each librarian should suppress desires for selfish independence and replace them with the realization that by working interdependently with another library, the librarian can assemble the rarities into a more valuable collection. A book's usefulness increases when it is acquired not as a rarity to place beside others on a shelf but as a book that contributes a new dimension to other sources available in the library on a specific author, subject, or theme. ${ }^{20}$ Similarly, a small number of books at one collection will increase in worth and in usefulness when related to books on the same or on a complementary theme at a neighboring library.

Support of the plan by library administrators is a third prerequisite. It is preferable to secure the endorsement of the rare book librarian's immediate superior and/or the library director in the beginning. Then the discussions and writing of the policy will more likely fit into the library's overall collection development program. If the plan is not endorsed at an early stage, the agreement should be sanctioned after it is written. Should personnel within the administration change, continued support should be obtained. Administrative support will help to ensure the continuance of the policy should different librarians take charge of the special collections. It also might encourage donors to give funds to each library to develop collections concurrently.

Fourthly, each participating librarian should recognize the criteria used in collecting books. These should not be sacrificed during the subsequent discussions outlining the acquisition areas of the agreement. One criterion may be derived from who in the local academic community uses the collection and how they use it. Does the collection serve as a pedagogical or as a research collection? The former supports an undergraduate curriculum or characterizes a small segment of material within a larger collection that is especially useful in teaching. The latter is demanded by welldeveloped university programs to support the original research expected of graduate students and faculty. Another criterion may be based on how much support is given to immediate and future use. All librarians acquire titles for faculty members' current needs as influenced by research trends. But at the same time, they should be selecting for tomorrow's scholars and anticipating future research trends. The ability to identify significant yet little-known works will enable a librarian to provide sources with new research potential. ${ }^{21}$

The fifth prerequisite to the cooperative discussions is for each participant to survey the collection. This study should produce a summary of a library's development and an analysis of the scope, possibly citing specific titles. With this knowledge, each curator will know what areas to share or to offer as complementary to the other cooperating institutions and what gaps to fill with holdings at the other libraries. The curator will also be able to form ideas on new collecting areas that might be adopted in developing the scope and quality of the cooperative endeavor.

Once the five prerequisites have been met, the next guidelines include a joint discussion among the librarians, outlining the collecting areas, conditions, and procedures to be specified in a written policy. As in all cooperative agreements, reciprocity is important, and each party should have something to contribute. 
There should be a recognition of each collection's unique strengths and the collecting areas each librarian wishes to continue to develop exclusively. Specific subjects at each library that complement each other should be noted and marked for continued development. Subjects of mutual interest should be singled out and the responsibility for them divided to avoid unnecessary duplication. Selection responsibilities in new areas should be assigned in order to enhance further the total plan.

The conditions of the agreement should also be discussed. Flexibility should be one goal of the working policy. The division of collecting areas should not impose a set of confining regulations but should offer guidelines in order to develop the subjects effectively. It should be understood that collecting areas can and should be modified to match shifts in research and teaching interests. ${ }^{23}$ Equally important is to set the level of duplication which is desirable and not to be eliminated. ${ }^{24} \mathrm{Du}$ plication is justified by use of a title or by its appropriateness to each collection's emphasis. Also, potential gifts should not be subject to the policy's guidelines. Therefore, duplication of titles due to donations is permissible.

Various procedures should be specified for maintenance of the agreement. An exchange of holdings information between the libraries is one characteristic of successful resource sharing programs. ${ }^{25}$ Knowing what another collection contains would help the librarian to eliminate unnecessary duplication, to decide the best location for a title, or to help a patron. Lists of books acquired in certain areas prior to the cooperative efforts or lists, compiled periodically, of titles acquired under the policy's guidelines would also be useful. Annual reports should be exchanged. Procedures for publicizing the joint holdings should be outlined. Each curator and staff should be responsible for talking to students, faculties, and visiting scholars to make them aware of the variety and depth of material offered. Written publicity is equally important.

Finally, it should be specified that the librarians meet periodically to review the viability of the cooperative program. Weaknesses can be identified and adjustments made to correct them. These review sessions may include reassignments of selection responsibilities due to shifts in teaching and research interests. Open discussions will allow each librarian to hear the others' desires and may reinforce the adaptability of the agreement, thereby strengthening its bonds.

\section{A WORKING POLICY}

In the fall of 1979, discussions were held between the curator of the Rare Book Collection at UNC-CH and the curator of Special Collections at UNC-G to initiate cooperation in the collecting of materials on the history of the printed book. Both libraries had been building their own resources in the subject prior to this time, and the proximity of the institutions-they are only fifty miles apart-supported development of a policy for a cooperative program.

In 1929, UNC-CH began collecting materials on the origin and development of the book. Clay tablets, papyri, medieval manuscripts, incunabula, sixteenthcentury imprints, nineteenth- and twentieth-century private press books, and books about books were acquired to strengthen sources for research on the book. Eventually, the collection was able to boast ownership of some of the earliest examples of color printing, typography, and bibliography as well as a significant collection of Victorian bookbindings.

Surveys in 1972 and 1973 of Special Collections at UNC-G revealed superior examples of private press books, books illustrated by artists, and works on illustrative techniques such as wood engraving and lithography. These holdings, in addition to statistics indicating heavy use of the collection by art students, encouraged further development in the books arts. Consequently, the library began to acquire more artists' books, books about books, a large group of English and American private press books, and American turn-ofthe-century small publishing firms' materials.

A cooperative collection development policy covering the history of the printed book was drawn up for the two libraries. ${ }^{26}$ 
The policy's objectives were (1) to gather books that would instill in students an appreciation of man's greatest intellectual ideas and how they have been preserved and passed down through the ages, (2) to show the development of the book as an art form, and (3) to encourage research and scholarship in the history of the printed book. The agreement specified that books would be selected to meet both present and future needs and that they would support the orientation of the institution of which each collection was a part. UNC-CH, with a well-developed graduate program, was to select primarily materials for advanced research; UNC-G was to concentrate on acquiring materials for use by the students and faculty of its primarily undergraduate curriculum. The policy recognized well-developed collecting areas as they existed at the time and established for each library new areas complementary to current holdings as well as to those of the neighboring institution.

The agreement outlined in detail the areas for which each library was responsible. A summary is offered here. UNC-CH elected to gather books in the following areas: the development of the book during the fifteenth and sixteenth centuries in Europe and Great Britain, including the work of prominent printers and publishers; the book as a vehicle for scholarship and transmission of knowledge; technological developments in bookmaking; book forgeries and facsimiles illustrating printing techniques; Victorian bookbindings; private press books published by proto-private presses of the fifteenth through the eighteenth centuries; outstanding examples from private presses of the eighteenth through the early twentieth centuries; and private press books written about books or by authors already collected. UNC-G chose to concentrate on the book arts in the mid-nineteenth and twentieth centuries, encompassing the following areas: private press books, primarily those printed by English and American presses but including select French ones and those exhibiting fine printing, decoration, and illustration; books illustrated by artists; aesthetic aspects of bookmaking; and small, turn-of- the-century American publishing firms. American trade bindings produced between 1840 and 1900 and children's illustrated books of the nineteenth and twentieth centuries were also included in UNC-G fields.

A comparison of the complementary areas shared between the two libraries illustrates how this combination was designed to provide a wealth of material. In the area of private press books, UNC-CH's acquisitions of fifteenth to eighteenth century publications and UNC-G's imprints from the mid-nineteenth century to the present day would offer stunning coverage. In the field of printing and bookmaking, UNC$\mathrm{CH}^{\prime}$ s concentration on technological developments would balance UNC-G's resources on aesthetic qualities in books. In the field of bindings, UNC-CH would gather Victorian examples produced in England between 1830 and 1900, and UNC-G would collect trade bindings made in the United States during the same period.

During the five years since the policy's implementation, the librarians have sought to follow policy guidelines in expanding their collections. ${ }^{27}$ Both librarians have received positive feedback on the program from their administrations. Book dealers were informed of the agreement. There has been profitable contact between the two curators; consultation before the acquisition of titles, for example, concerning the purchase of Dard Hunter's study of his father entitled The Life Work of Dard Hunter (1981); the referral from UNC-CH to UNC-G of a book dealer offering a splendid nineteenth-century American binding for sale; the reporting of UNC-G's private presses to $\mathrm{UNC}-\mathrm{CH}$; and an exchange of information on bindings and of annual reports. Both collections' holdings have been reported to the editors of reference books and online bibliographies. One will find reports from the collections side by side in Rare Books $1983-84 .{ }^{28} \mathrm{~A}$ search of the Eighteenth-Century Short-Title Catalogue database will retrieve different titles at each library that were printed by Horace Walpole at his Strawberry Hill Press. Each librarian has referred researchers, including library science stu- 
dents, art students, bookbinders, and papermakers, to the other institution. A mutual review of the collecting areas produced some shifting of responsibilities due to new research trends and brought on a further refinement of the division of fields. UNC-CH is seeking now to limit its acquisitions of private press books but to expand its collection of Victorian bindings to include the production and materials of nineteenth-century books. UNC-G redefined its European private press acquisitions to encompass books from German private presses and to concentrate on books illustrated specifically by French artists. Other changes for UNC-G include a greater emphasis on nineteenth-century children's books and on twentiethcentury English private presses. Previous standing orders with private presses have been maintained although the selected acquisitions of other presses have been reduced. Finally, cooperation is being extended to detective fiction acquisitions with Wake Forest University in WinstonSalem, North Carolina, also participating.

Both librarians feel that the value and usefulness of their special collections have been enhanced by the agreement. Together, the libraries offer a gold mine of sources for research in the history of the printed book. Perhaps with this example of thriving cooperation, other small collections will combine forces to present to the public larger selections of materials for study, books to give rise to new pleasures in the pursuit of knowledge.

\section{REFERENCES}

1. Scholarly Communication: The Report of the National Enquiry (Baltimore: Johns Hopkins Univ. Pr., 1979), p.32.

2. T. S. Eliot, "Tradition and the Individual Talent," in his Selected Essays (New York: HBJ, 1950), p.4.

3. Rose Mary Magrill, "The Concept of Resource Sharing," Canadian Library Journal 35:356 (Oct. 1978); Susan E. Davis, "Collection Development and the Special Subject Repository," Bookmark 39:102-103 (Winter 1981); and F. Gerald Ham, "Archival Choices: Managing the Historical Record in an Age of Abundance," American Archivist 47:13-15 (Winter 1984).

4. Patricia Battin, "Research Libraries in the Network Environment: The Case for Cooperation," Journal of Academic Librarianship 6:72-73 (May 1980).

5. Warren J. Haas, "Managing Our Academic Libraries: Ways and Means," College \& Research Libraries 40:110 (Mar. 1979).

6. Gordon R. Williams, "The Function and Methods of Libraries in the Diffusion of Knowledge," Library Quarterly 50:74 (Jan. 1980).

7. Jay K. Lucker, "Library Resources and Bibliographic Control," College \& Research Libraries 40:145 (Mar. 1979); and Allen Kent and others, Use of Library Materials: The University of Pittsburgh Study (New York: Dekker, 1979), p. 191.

8. Interview with Paul S. Koda, Rare Book Collection, Wilson Library, University of North Carolina, Chapel Hill, N.C., September 6, December 1, 1979; and Anna H. Perrault, "Cooperative Acquisitions: Not an Easy Thing to Do," LLA Bulletin 44:17 (Summer 1981).

9. "Policy and Administration," in Rare Books in the University Library (Chicago: Association of College and Reference Libraries, 1949), p.8.

10. Interview with Paul S. Koda, Rare Book Collection, Wilson Library, University of North Carolina, Chapel Hill, N.C., September 26, 1979.

11. Ibid., September 6, December 1, 1979.

12. Perrault, "Cooperative Acquisitions," p.17.

13. W. J. Cameron, comp., A Short-Title Catalogue of Books Printed in Britain and British Books Printed Abroad 1641-1700 Held in Australian Libraries (Sydney: Wentworth Pr., 1962), p.xiv-xix, passim.

14. Robert L. Balliot, "A Program for the Cooperative Acquisition and Use of Library Materials of Seven New England Liberal Arts Colleges (CONVAL) Based on an Analysis of Their Collections," Bureau of Research, no. 9-A-046 (Washington, D.C.: Bureau of Research, Office of Education, U.S. Department of Health, Education, and Welfare, June 1970), p.23-24, 71.

15. Robert L. Volz to the author, November 20, 1979; Ralph S. Emerick to the author, November 27, 
1979; and John Lancaster to the author, November 21, 1979.

16. Paul H. Mosher and Marcia Pankake, "A Guide to Coordinated and Cooperative Collection Development," Library Resources \& Technical Services 27:417-31 (Oct./Dec. 1983).

17. Robert B. Downs, "Problems in the Acquisition of Research Materials," in The Acquisition and Cataloguing of Books, ed. William M. Randall (Chicago: Univ. of Chicago Pr., 1940), p.66; and Bernard Naylor, "Steady-State and Library Cooperation," in Steady-State, Zero Growth and the Academic Library, ed. Colin Steele (Hamden, Conn.: Linnet Books, 1978), p.123.

18. Ralph T. Esterquest, "Aspects of Library Cooperation," College \& Research Libraries 19:204 (May 1958); and Jacqueline W. Felter, "Library Cooperation: Wave of the Future or Ripple?" Bulletin of the Medical Library Association 63:6 (Jan. 1975).

19. Charles A. Nelson, Richard H. Logsdon, and Scott Adams, "Library Cooperation: Panacea or Pitfall?" Special Libraries 56:572 (Oct. 1965).

20. Paul S. Koda, "Collecting Rare Books for a University Library," Library Acquisitions: Practice and Theory 1:140 (1977).

21. Ibid., p.145.

22. Lucker, "Library Resources," p.145; Magrill, "Concept," p.355-56; Downs, "Problems," p.66.

23. Downs, "Problems," p.66.

24. Ibid.

26. A copy of the policy may be found in Martha Marshall Smith, "Cooperative Collection Development in Rare Books among Neighboring Academic Libraries" (M.S.L.S. paper, University of North Carolina at Chapel Hill, 1979), p.22-26.

27. The following summary is based upon a written survey completed by Paul S. Koda, the rare book librarian at UNC-CH, and Emilie W. Mills, the special collections librarian at UNC-G, August 1982, and upon Emilie W. Mills to the author, July 13, 1984.

28. Rare Books 1983-84: Trends, Collections, Sources, ed. Alice D. Schreyer (New York: Bowker, 1984), p. 260 . 


\section{We have products and services too numerous to list. So we won't.}

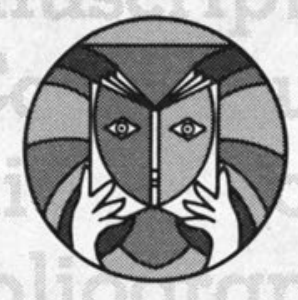

But we will give you one convenient number to call. 996-6128 or write us at: National Library of Canada 395 Wellington Street, Ottawa, Ontario KIA ON4 